Benzer, A. ve Saraçoğlu, K. (2020). Türkçe öğretmenlerinin karşılaştıkları sorunların, sorunlara yönelik eleştiri ve önerilerin sosyal medya üzerinden incelenmesi. Ana Dili Eğitimi Dergisi, 8(4), 1115-1132.

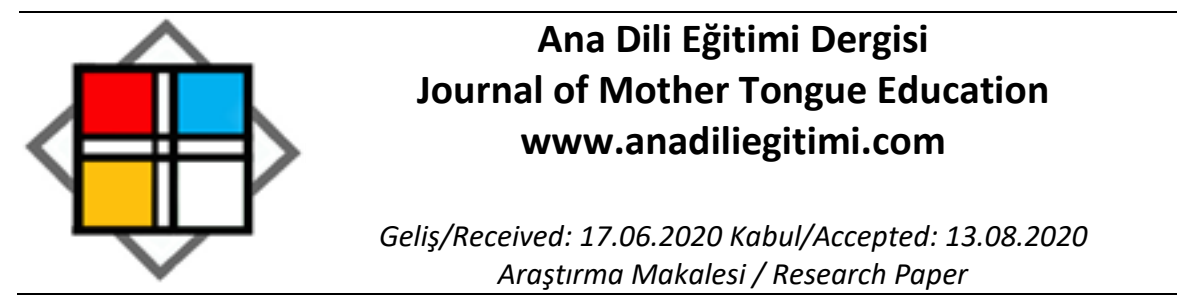

\title{
Türkçe Öğretmenlerinin Karşılaştıkları Sorunların, Sorunlara Yönelik Eleştiri ve Önerilerin Sosyal Medya Üzerinden İncelenmesi*
}

\author{
Ahmet BENZER ${ }^{* *}$ \\ Kübra SARAÇOĞLU ${ }^{* * *}$
}

\begin{abstract}
Öz
Sosyal medya, aynı meslekte benzer sorunları yaşayan insanlar için duygu ve düşüncelerini paylaşma imkânı tanıması bakımından büyük önem taşımaktadır. Bu araştırmada Facebook üzerinden Türkçe öğretmenlerinin alan ve mesleklerine ait soru, öneri ve eleştirileri incelenecektir. Bu doğrultuda hem mevcut durumu görme hem de lisans eğitimi dâhil olmak üzere devam eden veya geliştirilecek yeni programlara dair bilgi ve gerekçe sağlayacak bir veri elde etmek amaçlanmıştır. Araştırmanın modeli durum çalışması olarak belirlenmiştir. Araştırma verileri için Türkçe öğretmenlerinden oluşan bir Facebook grubu seçilmiştir. 1 Eylül 2015 ile 31 Ağustos 2018 tarihleri arasındaki 8.372 gönderi araştırma inceleme nesnesini oluşturmuştur. Araştırma sonuçlarına göre Türkçe öğretmenleri "dil bilgisi ve dil bilgisi öğretimi" (3.560), "temel dil becerilerini geliştirme" (2.079), "okul içi etkinlikler" (979), "kelime öğretimi" (632), "mesleki gelişim" (452), "ölçme ve değerlendirme" (392), "ders materyalleri" (388) "projeler" (250) konularında bilgi ve görüş alışverişinde bulunmuşlardır. Araştırma sonucunda sosyal medya üzerinden öğretmen grupları düzenli taranarak elde edilen bilgilerin hizmet öncesi ve hizmet içi eğitimlerinin işlevsel olarak planlanmasında etkin kullanılması önerilmiştir. Bu veriler aynı zamanda doğrudan sahadaki uygulayıcıların düşünceleriyle şekillenen işlevsel bir eğitim programlamasına imkân sağlayacaktır.
\end{abstract}

Anahtar Kelimeler: Türkçe öğretmeni, Facebook grubu, Türkçe eğitimi.

\section{Examining the Problems, Criticisms and Suggestions of Turkish Teachers on Social Media}

\begin{abstract}
Social media is of great importance in terms of allowing people to share their feelings and thoughts for people with similar problems in the same profession. In this research, questions, suggestions and criticisms of the fields and professions of Turkish teachers were examined on Facebook. In this direction, present study aims to obtain data that provide information and justification for both ongoing and future new programs including undergraduate education. The study is designed as a case study. A facebook group of Turkish teacher and 8,372 posts between September 1, 2015 and August 31, 2018 were selected for the data. According to the results of the research, Turkish teachers consulted with each other mostly about "grammar and grammar teaching" (3560), "developing basic language skills" (2079), "in-school activities" (979), "vocabulary teaching" (632), "professional development" (452) exchanged information on "measurement and evaluation" (392), "course materials" (388), "projects" (250). As a result of the study, it was proposed to use the information obtained by regularly scanning teacher groups
\end{abstract}

\footnotetext{
${ }^{*}$ Bu çalışma Doç. Dr. Ahmet Benzer'in danışmanlığında yürütülen adlı yüksek lisans tezinden üretilmiştir. ** Doç. Dr., Marmara Üniversitesi, Atatürk Eğitim Fakültesi, Türkçe Eğitimi Bölümü, İstanbul, ahmetbenzer@gmail.com, ORCID: 0000-0003-3579-3699

${ }^{* * *}$ Yüksek Lisans Öğrencisi, Marmara Üniversitesi, Atatürk Eğitim Fakültesi, Türkçe Eğitimi Bölümü, İstanbul, ogr.kbr.srcgl@gmail.com, ORCID: 0000-0002-0826-2131
} 
on social media, in the functional planning of pre-service and in-service training. The findings will also allow for a functional training program directly shaped by the opinions of the practitioners in the field.

Keywords: Turkish teacher, facebook group, Turkish education.

\section{Giriş}

Dünyada teknoloji hızlı bir şekilde gelişirken uzak mesafeler yakınlaşmış ve dünya küçük bir köy hâline gelmiştir. Bu dünyada ancak kendilerini yenileyip değişime ayak uydurabilenler başarılı kalmıştır. Teknolojinin ilerlemesi ve özellikle internetin yaygınlaşması eğitim alanını da etkilemiş, öğretmenler tarafından takip edilmeye ve kullanılmaya başlanmıştır. Günümüzde yüz yüze iletişim anlayışı değişmiş yerini akıllı telefon ya da bilgisayar ile kolayca ulaşabileceğimiz yaygın iletişim ağı olan sosyal medyaya bırakmıştır. Sosyal medya üzerinden öğretmenler soru, eleştiri ve önerilerini doğrudan uzmana ulaştırabilme ve meslektaşlarıyla iletişim kurabilme amaçlarıyla gruplara katılmışlardır. Sosyal medya; kullanıcıların sosyal ağ üzerinde kişisel sayfalarını kurabildikleri, fotoğraf, düşünce, haber ve bilgi gibi içerikler oluşturup paylaşabildikleri, mesaj ve sohbet özellikleri ile diğer kullanıcılarla haberleşebildikleri çevrimiçi medyadır (Boyd ve Ellison, 2007: 211; Preeti, 2009: 130; Vural ve Bat, 2010: 3351; Siddiqui ve Singh, 2016: 71). Mayfield (2008: 5) sosyal medyanın özelliklerini şu şekilde sıralar: kullanıcılara katılım rahatlığı sağlama (katılımcılar), içeriklere ulaşma ve kullanıcıların görüşlerine açık olma (açıklık), çift yönlü iletişim kurma (konuşma), insanların aktif biçimde birbiriyle bağlantı kurabilmesi ve fikir paylaşma (topluluk), farklı sosyal ağlar ve sitelerle bağlantılı olma (bağlantılılık).

Video yükleme ve izleme, fotoğraf ve görüş paylaşma, içerik düzenleme, bloglar oluşturma gibi farklı amaçlarla kurulmuş ve kullanılan birçok sosyal medya aracı vardır. Bu araçlar, kullanıcıların istekleri ve yaratıcılarının ortaya çıkarmasına bağlı olarak kendine üyeler katar. Sürekli yeni ağlar ortaya çıktığı için "sosyal medya" türlerinin sabit bir sıralamasının yapılması güç (Başer, 2014: 15) olsa da Facebook gibi sosyal ağ, Flickr gibi fotoğraf paylaşım ağı, Youtube gibi video paylaşım ağı, Linkedln gibi iş ağı, Twitter gibi mikro bloglama gibi pek çok türde sosyal medya aracı bulunmaktadır (Whiting ve Williams, 2013: 363).

Öğretmenler meslek hayatlarının çeşitli dönemlerinde farklı sorunlarla karşılaşırlar. Bununla birlikte öğretmenlerin yüksek iş yükü vardır (Hooftman, Mars, Janssen, Vroome ve Bossche, 2015: 95). Onların meslek hayatlarında karşılaştıkları problemler: deneyim eksikliği, lisans eğitiminin yetersizliği, öğrenci özellikleri, öğretim programı ve ders kitapları, mesleki yetersizlik, kalabalık sınıflar, bireysel farklılıklar, yönetici desteği, velilerle iletişim, rehber öğretmen desteği, yabancılık duygusu, oryantasyon eksikliği, mesleki gelişim, mesleki donanım yetersizliği, profesyonel destek ihtiyacı, beklenti/farkındalık eksikliği, çevreye uyum, köy koşulları, sosyo-kültürel farklılıklar, toplumun bakış açısı, sosyal olanakların yetersizliği, kültürel etkinliklerin yetersizliği, öğretim materyallerine erişim, öğrencilerin maddi yetersizlikleri, okul mimarisindeki eksiklikler, okulda yaşam alanının olmaması, sınıfların donanım yetersizlikleri, sınıflarda kullanım alanının yetersiz olması, sınıfların fiziksel yetersizlikleri şeklinde sıralanabilir (Kozikoğlu ve Senemoğlu, 2018: 347-361). Buna ek olarak öğretmenler; öğretme sürecinin dışında mesleki saygınlığın azalması, MEB politikalarının sıklıkla değişmesi, idare, veli ve öğrencilerle yaşanan sorunlar, fiziki koşulların yeterli olmaması, kalabalık sınıflar, meslektaş ve idarecilerle iletişim, öğretmen yetiştirme problemleri, iş yükünün fazlalığı, alt yapı sorunları, özlük hakları ve sendikal faaliyetlerle ilgili problemlerle de yüz yüze gelirler (Seferoğlu, 2001: 16; Esen, Temel ve Demir, 2017: 59). Dünya genelinde maaş, öğretmen hazırlık programları, iş yükü ve çalışma koşulları gibi nedenler öğretmenleri meslek hayatlarındaki itici faktörler olmuştur (Geiger ve Pivovarova, 2018: 605).

Sahadaki öğretmenlerin karşılaştıkları sorunları çözmek soru ve sorunlarına anında çözüm bulmak için deneyimli öğretmenlerden fikir alması zorunlu bir ihtiyaçtır. Öğretmenler mesleki faaliyetlerinde diğer öğretmenlere ve onların desteklemelerine gereksinim duyarlar (Ergüney, 2019: 2). Birçok ülkede meslek hayatlarının başındaki öğretmenlerin oldukça yıprandıkları belirlenmiş, bu durumun oluşmaması için diğer öğretmenlerden destek ve yardım alması gerektiği ifade edilmiştir (Ingersoll ve Strong, 2011: 211; Long ve diğerleri, 2012: 24). Sosyal medyada öğretmenler tarafından 
kurulmuş gruplar öğretmenlere meslektaşları ile fikir alışverişi yapmak, çalışmalarını desteklemek, soru sormak ve sorularını yanıtlamak, onların deneyimlerinden yararlanmak açısından olumlu etkisi ve mesleki gelişimlerine katkısı vardır (Deniz, 2016: 86-87; Ergüney, 2019; 175-178; Afşin, 2019: 62). Öğretmenler sosyal medya vasıtasıyla kendi çalışmalarını meslektaşlarıyla paylaşabildikleri gibi meslektaşlarının çalışmalarına ve deneyimlerine de ulaşabilmektedir. Öğretmenler arasındaki bu durum bir dayanışmadır. Sosyal medya gibi kanallardan elde edilen veriler ile hizmet öncesi ve içi intiyaç belirleme çalışmaları için fikir olabilir (Ünüvar, Çalışandemir ve Tagay, 2018: 22).

Teknolojiden etkilenen başlıca kısımlar ders materyalleri ve öğretim süreci tasarımları olurken sınıf ortamı da bu değişiklikten geri kalmamış, standart öğrenme mekânı anlayışı sınıf duvarlarının dışına taşmıştır. Öğretmenler sosyal ağlar aracılığıyla öğrencilerle bağlantı kurmuş ve onların dünyası ile eğitim sistemini ilişkilendirmiştir (Alabdulkareem, 2015: 216; Öztürk ve Talas, 2015: 115; Arkan ve Yünter, 2018: 5). Teknolojik ilerlemeler eğitim sistemine dahil edilmiştir. Sosyal ağlar esnekliği, kullanıcıdan yana tavrı, kullanım kolaylığı özellikleri ile öğrenciler ve araştırmacılara haberleşme, bağlantı kurma ve geri bildirim olanakları sağlamaktadır (Gülbahar, Kalelioğlu ve Madran, 2010: 2). Öğretmenler sosyal ağları, veli bilgilendirme, meslektaşlarla iletişim, mesleğe ve branşlarına dair gelişmeleri izleme, hızlı bağlantı kurma, dokümanlara ulaşma, öğrencileri takip etme, ödev verme, öğrencilerle etkileşim gibi amaçlarla da kullanmaktadır (Menteşe, 2013: 13-16).

Sosyal medya araçlarından Facebook, kullanıcı sayısının fazlalığı, grup kurma gibi özellikleri ile dikkat çekicidir. Nitekim Facebook'ta öğretmenlere yönelik kurulan pek çok grup vardır. Facebook gruplarında öğretmenler öğretim programları, ders kitapları yahut ders süreciyle ilgili kararsız kaldıkları noktaları danışabilmekte, uyguladıkları etkinlikleri paylaşabilmekte, çeşitli doküman ve belgeye ulaşabilmekte, sistemdeki değişiklerden haberdar olabilmekte, okul ya da sınıf içinde veyahut veli ile ilgili yaşadıkları problemler üzerine tecrübeli öğretmenlerden yararlanabilmektedir. Facebook işbirlikli öğrenme, araştırma, sorgulama, problem çözme ve tartışma gibi amaçlarla eğitimde kullanılabilir (Gülbahar, Kalelioğlu ve Madran, 2010: 3). Öğretmenler ve okul müdürleri sosyal ağlar üzerinden eğitimin öğrenci istekliliğini, dönütünü, okul ve öğrenci ilişkisini artırdığı düşünmektedir. Buna ek olarak öğretim ortamına, ders sürecine, öğrenciye hitap etme, materyallere ulaşma ve paylaşma açısından fayda sağlamaktadır (Menteşe, 2013: 13-16). Sosyal medyanın eğitimde kullanılması öğretmenleri meslek ve birey anlamında desteklemiş ve motivasyonunu artmasına katkı sağlamaktadır (Sarsar, Başbay ve Başbay, 2015: 427).

Türkçe öğretimi içinde var olan beceriler, aslında bir ara beceri olup yalnızca Türkçe dersi ile sınırlı değil, diğer derslerde de başarının olmazsa olmazıdır. Araştırmada Türkçe öğretmenlerinin soru, öneri ve eleştirilerini ifade ettikleri paylaşımlar ele alınmıştır. Bu odak noktası araştırma için seçilirken Türkçenin işleyişine, sahadaki uygulamasına dönük pek çok çıkarıma ulaşmak ve bilgi almak amaçlanmıştır. Araştırmada öğretmen görüşleri, tartışmaları ve sorunları günümüz iletişim araçlarından birisi olan sosyal medya üzerinden otantik kayıtlarla incelenmiştir. Türkçe öğretmenlerinin sorunlarını büyük bir pencereden incelemesi, insanların kendilerini özgürce ifade ettikleri bir ortamda verilerin doğal bir ortamda, sosyal medya gibi son teknoloji iletişim aracı üzerinden toplanması, oldukça fazla kişiye ulaşması bakımından bu çalışma oldukça mühimdir. Çalışmanın genel amacı ışığında problem cümlesi "Türkçe öğretmenlerinin Facebook üzerinden soru, eleştiri ve önerileri nelerdir?" olarak belirlenmiştir. Bu genel amaca ulaşabilmek için Türkçe öğretmenlerinin dil bilgisi ve dil bilgisi öğretimi, temel dil becerileri, okul içi etkinlikler, kelime öğretimi, mesleki gelişim, ders materyalleri, proje hazırlama gibi noktalardaki paylaşımları incelenmiştir. Bu araştırmanın MEB politikalarına, eğitim ve öğretim sistemine ve araştırmacılara yeni ufuklar açacağı düşünülmektedir.

\section{Araştırmanın Modeli}

\section{Yöntem}

$\mathrm{Bu}$ araştırmanın modeli, nitel araştırma yöntemlerinden durum çalışması olarak belirlenmiştir. Durum çalışması; araştırma durumunun doğal ortamında elde edilen verilerin sistematik bir şekilde toplanması, analiz edilmesi ve çıkan sonuçların nedenine cevap arayarak durumun ayrıntılı betimlemelerle olduğu gibi anlatılmasıdır (Yıldırım ve Şimşek, 2011: 77). 


\section{Verileri Toplama Aracı}

Araştırmanın veri toplama aracı olarak sosyal medya ağı olan Facebook seçilmiştir. Ardından Facebook'ta Türkçe öğretmenleri tarafından oluşturulmuş bir gruptaki 1 Eylül 2015 ile 31 Ağustos 2018 tarihleri arasındaki 8.372 paylaşım “Ekran Alıntısı Aracı" ile toplanmıştır.

\section{Verilerin Analizi}

Türkçe öğretmenlerinin problem yaşadıkları alanları ve bu alanların yoğunluk durumunu saptamak amacıyla bu çalışmadaki veriler "içerik analizi tekniği" ile incelenmiştir. İçerik analizi; farklı disiplinlerdeki birçok araştırma sorusuna yanıt aramak üzere toplanan verileri açıklamak ve anlamlandırmak için elde edilen verilerin belli kurallar dahilinde kodlanması, temaların belirlenmesi, kodların ve temaların düzenlenmesi ve tanımlanması şeklinde aşamalarından oluşan sistematik ve tarafsız bir tekniktir (Yıldırım ve Şimşek, 2011: 227-228).

ilk olarak araştırmaya konu olan Facebook grubunun Ağustos 2018 tarihindeki verileri toplanmıştır. İki alan uzmanı ve araştırmacının görüş birliği ile araştırma sürecinden elde edilen verilerin 36 aylık bir süreci kapsaması kararlaştırılmıştır. "Ekran Alıntısı Aracı" ile toplanan veriler ay ve yıl şeklinde adlandırılan dosyalarda biriktirilmiş ve her bir ekran alıntısı numaralandırılmıştır. Araştırma kapsamında paylaşımlardan kendi içinde benzerlik gösterenler bir araya getirilerek kodlar oluşturulmuştur. Ortaya çıkan kodlar arasında ortak noktaları bulunanlar ve ilişkili olanlar birleştirilerek kategoriler ortaya çıkmıştır. Kategorilerin de birleşmesi ile temalar meydana getirilmiştir. Kod ve temalar iki alan uzmanının görüşüne sunulmuştur. Illk aşamada "dil bilgisi ve dil bilgisi öğretimi", "temel dil becerileri", "kelime öğretimi", "sınavlar", "sözel mantık soruları", "değerler eğitimi", "ders kitabı", "kaynaklar", "etkinlikler", "pano düzenleme", "belirli gün ve haftalar", "mesleki görüş alışverişi", "projeler" şeklinde olan temalar meydana gelmiştir.

Temalar arasındaki bağlantılar tespit edilerek alan uzmanının ve araştırmacının ortak görüşleri ışığında "dil bilgisi ve dil bilgisi öğretimi", "temel dil becerileri", "kelime öğretimi", "ölçme ve değerlendirme", "okul içi etkinlikler", "mesleki gelişim", "ders materyalleri" ve projeler" temaları biçiminde son hâlini almıştır.

Araştırma süreci, verilerin toplanması ve verilerin analizi boyunca alan uzmanına danışılması araştırmanın geçerliğini sağlamıştır. Çalışma amacı göz önüne alınarak araştırma inceleme nesneleri seçilmiş, veri toplanma ve analiz süreci detaylıca aktarılmış, bu da geçerliğe katkı sağlamıştır. Araştırma verileri açık ve net şekilde açıklanmış, anlamlı ve tutarlı olduğu belirlenmiştir.

Çalışmanın analiz sürecinde Türkçe öğretmenlerinin paylaşımlarının analizinde içerik analizi kullanılmıştır. Öncelikle veriler detaylıca incelenmiş, sonra birbirine benzeyen veriler temalarla bir araya getirilmiştir. Bunun sonucunda temalar ve alt temalar oluşturulmuştur. Çalışmanın güvenirliğini sağlamak adına çalışma içinden rastgele seçilmiş 100 paylaşım bir alan uzmanı ve araştırmacı tarafından birbirinden bağımsız olacak biçimde kodlama işlemini gerçekleştirilmiştir. Bu sürecinin sonunda alan uzmanı ve araştırmacının çalışmaları karşılaştırılmış ve çalışmanın güvenirliği hesaplanmaya çalışımıştır. Güvenirlik için Miles ve Huberman (1994)'ın iki puanlayıcı arasındaki uyumu incelediği "uyuşum yüzdesi formülü" kullanılmıştır. Buna göre araştırmacı ve alan uzmanının uyuşum yüzdesi 0.90 hesaplanmıştır. Uyuşum yüzdesinin 0.70 olması kabul edilebilir bir oranken bu çalışmanın 0.90 değerindeki uyumu çalışmada yüksek miktarda bir uyum olduğunu göstermektedir. Güvenirliği yüksek olan bu çalışmadan elde edilen bulgular sıklıkları ile tablolar şeklinde sunulmuştur.

\section{Bulgular}

Bu çalışmada Türkçe öğretmenlerinin alana ve mesleğe dair soruları, önerileri ve eleştirileri "dil bilgisi ve dil bilgisi öğretimi", "temel dil becerilerini geliştirme", "okul içi etkinlikler", "kelime öğretimi", "mesleki gelişim", "ölçme ve değerlendirme", "ders materyalleri" ve "projeler" olmak üzere sekiz başlıkta toplanmıştır (Şekil 1). Bazı paylaşımlarda birden fazla soru olduğu için tablolardaki sıklıklar paylaşım sayısını geçmiştir. 
Türkçe Öğretmenlerinin Karşılaştıkları Sorunların, Sorunlara Yönelik Eleştiri ve Önerilerin Sosyal Medya Üzerinden İncelenmesi

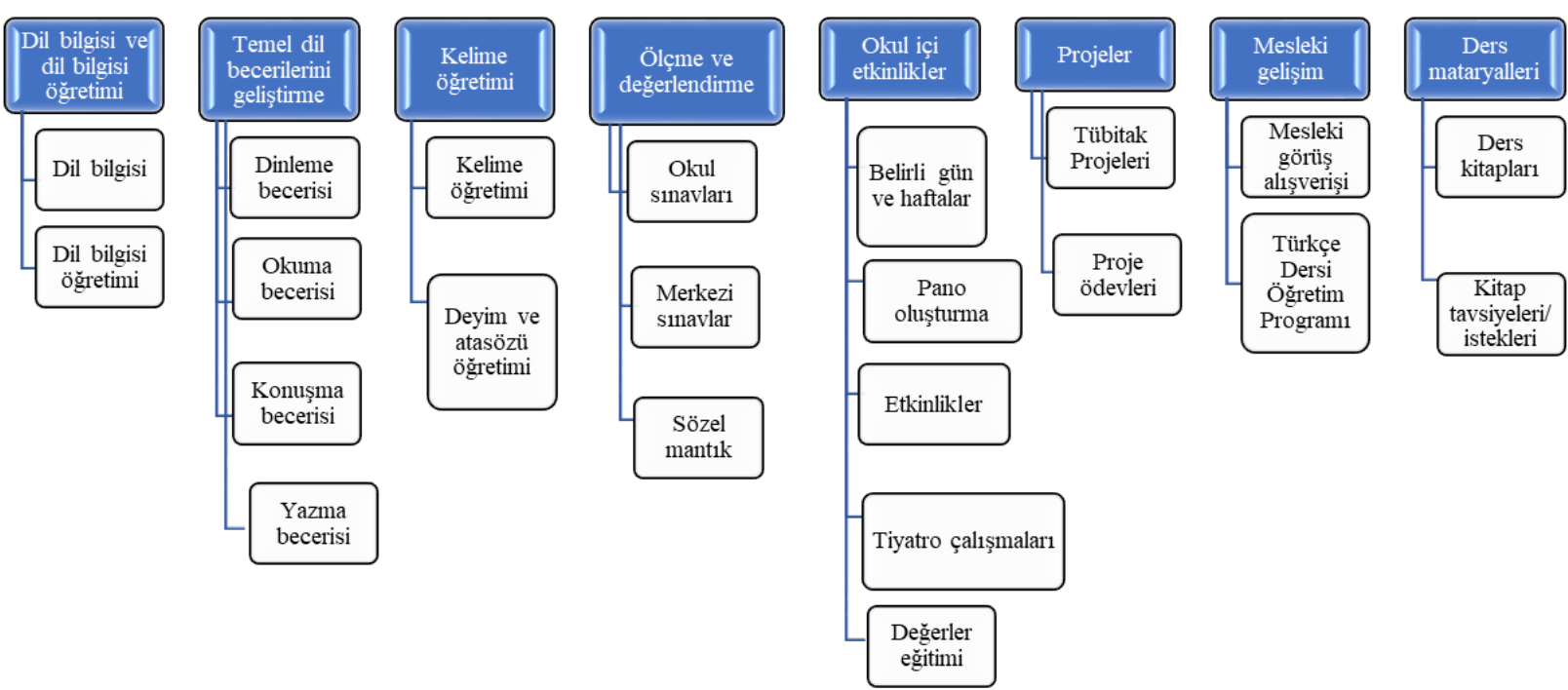

Şekil 1. Türkçe Öğretmenlerin Görüş Alışverişi Yaptıkları Konular

Türkçe öğretmenlerinin konuştukları konuların dağılımları incelenmiş, verilerin yüzde ve sıklık dağılımı Tablo 1'de görülmektedir:

Tablo 1.

Türkçe öğretmenlerinin tartışmalarının dağılımı

\begin{tabular}{lll}
\hline & Sıklık & Yüzde \\
\hline Dil bilgisi ve dil bilgisi öğretimi & 3.560 & 42.52 \\
Temel dil becerileri & 2.079 & 24.83 \\
Okul içi etkinlikler & 979 & 11.69 \\
Kelime öğretimi & 632 & 7.54 \\
Mesleki gelişim & 452 & 5.39 \\
Ölçme ve değerlendirme & 392 & 4.68 \\
Ders materyalleri & 388 & 4.63 \\
Projeler & 250 & 2.98 \\
\hline Toplam & 8372 & 100 \\
\hline
\end{tabular}

Tablo 1 incelendiğinde 8.372 paylaşımın 3.560'ı “dil bilgisi ve dil bilgisi öğretimi”nde yer alarak en çok tartışılan tema olmuştur. TÜBіTAK projeleri ve proje ödevleriyle ilgili soruların bulunduğu "projeler" başlığı en az konuşulan tema olarak belirlenmiştir $(f=250)$. Temel dil becerileri olan dinleme, okuma, konuşma ve yazmaya dair 2.079 paylaşım yapılmıştır. Dil becerileri içinde 1.986 paylaşım ile okuma becerisi ilk sırada bulunurken 29 paylaşım ile konuşma becerisi son sırada yer almıştır. Yazma $(f=67)$ ile dinleme becerisi $(f=57)$ yakın miktarlarda konuşulmuştur. Kelime öğretimi için de çalışmaları düzen $(f=632)$. Mesleki anlamda öğretmenler birbirleri ile görüş alışverişi yapmıştır $(f=452)$.

\section{Dil Bilgisi}

Dil bilgisi konularında yaşanan problemlerin dağılımı incelenmiş, elde edilen veriler Tablo 2'de görülmektedir: 
Tablo 2.

Dil bilgisi konularının tartışılma sıklığı

\begin{tabular}{|c|c|c|c|}
\hline & & Sıklık & Yüzde \\
\hline \multirow[t]{12}{*}{ Dil Bilgisi } & Ekler ve kökler sorusu & 348 & 9.77 \\
\hline & Kelime türleri sorusu & 333 & 9.35 \\
\hline & Fiilimsiler sorusu & 287 & 8.06 \\
\hline & Cümlenin ögeleri sorusu & 274 & 7.69 \\
\hline & Cümle türleri sorusu & 197 & 5.53 \\
\hline & Anlatım bozuklukları sorusu & 188 & 5.28 \\
\hline & Fiilde çatı sorusu & 169 & 5.28 \\
\hline & Ses olayları sorusu & 163 & 4.57 \\
\hline & Fiil sorusu & 141 & 3.96 \\
\hline & Sözcükte yapı sorusu & 120 & 3.37 \\
\hline & Kelime grubu sorusu & 81 & 2.27 \\
\hline & Ek fiil sorusu & 62 & 1.74 \\
\hline \multirow[t]{9}{*}{ Yazım Kuralları } & Yazımı karıştırılan kelimelerin yazımı & 326 & 9.15 \\
\hline & Bitişik ve ayrı yazılan kelimelerin yazımı & 228 & 6.40 \\
\hline & Büyük harfin kullanımı & 173 & 4.85 \\
\hline & De, mi ve ki'nin doğru yazımı & 72 & 2.02 \\
\hline & Sayıları yazımı & 30 & 0.84 \\
\hline & Kısaltmaların yazımı & 28 & 0.78 \\
\hline & Satır sonuna sığmayan kelimelerin yazımı & 11 & 0.30 \\
\hline & Düzeltme işaretinin kullanımı & 10 & 0.28 \\
\hline & Ek fiillerin yazımı & 4 & 0.11 \\
\hline \multirow[t]{12}{*}{ Noktalama İşaretleri } & Virgülün doğru kullanımı & 95 & 2.66 \\
\hline & Kesme işaretinin doğru kullanımı & 68 & 1.91 \\
\hline & Noktalı virgülün doğru kullanımı & 49 & 1.37 \\
\hline & İki noktanın doğru kullanımı & 35 & 0.98 \\
\hline & Noktanın doğru kullanımı & 24 & 0.67 \\
\hline & Üç noktanın doğru kullanımı & 8 & 0.22 \\
\hline & Konuşma çizgisinin doğru kullanımı & 6 & 0.16 \\
\hline & Soru işaretinin doğru kullanımı & 5 & 0.14 \\
\hline & Tırnak işaretinin doğru kullanımı & 5 & 0.14 \\
\hline & Ünlem işaretinin doğru kullanımı & 5 & 0.14 \\
\hline & Ayracın doğru kullanımı & 5 & 0.14 \\
\hline & Eğik çizginin doğru kullanımı & 2 & 0.05 \\
\hline Toplam & & 3.560 & 100 \\
\hline
\end{tabular}

Tablo 2 ele alındığında "Dil bilgisi" ana temasındaki 3560 paylaşımın 2.372'si dil bilgisi, 882'si yazım kuralları ve 307 'si noktalama işaretleri hakkındadır.

\section{Dil Bilgisi Öğretimi}

Dil bilgisi öğretiminde yaşanan problemlerin dağılımı incelenmiş, elde edilen veriler Tablo 3'te görülmektedir:

Tablo 3.

Dil bilgisi öğretimine dair konuşulanların dağılımı

Sıklık Yüzde


Türkçe Öğretmenlerinin Karşılaştıkları Sorunların, Sorunlara Yönelik Eleştiri ve Önerilerin Sosyal Medya Üzerinden İncelenmesi

\begin{tabular}{lll}
\hline Temel dil bilgisi kurallarına dair bilgi eksikliği & 3.127 & 87.83 \\
Konu anlatımı & 215 & 6.03 \\
Çalışma sayfası & 80 & 2.24 \\
Materyal tasarımı & 65 & 1.82 \\
Eğitsel oyunların hazırlanması & 43 & 1.20 \\
Kavram tespiti & 31 & 0.87 \\
\hline Toplam & 3.560 & 100 \\
\hline
\end{tabular}

Tablo 3'e bakıldığında dil bilgisi öğretiminde en önemli sorun büyük bir fark ile bilgi eksikliğine bağlıdır ( $f=3.127)$. Konu anlatımı $(f=215)$ dil bilgisi öğretimindeki ikinci sorundur. Bunun yanı sıra çalışma sayfası ( $f=80$ ), materyal tasarımı $(f=65)$ ve eğitsel oyun tasarlama gibi kodlar da dil bilgisi öğretimindeki sorun meydana getiren diğer hususlardır. En az sorun oluşturan unsur ise kavram tespitidir $(\mathrm{f}=31)$.

\section{Temel Dil Becerileri}

Temel dil becerileri ile ilgili toplanan veriler doğrultusunda tartışılan konuların dağılımı Tablo 4'te görülmektedir:

Tablo 4.

Temel dil becerilerine dair konuşulanların dağılımı

\begin{tabular}{llll}
\hline & \multicolumn{1}{c}{ Kodlar } & Sıklık & Yüzde \\
\hline Okuma becerisi & Paragrafta anlam sorusu sorma & 655 & 31.50 \\
& Sözcükte anlam sorusu sorma & 464 & 22.31 \\
& Cümlede anlam sorusu sorma & 320 & 15.39 \\
& Metin türleri sorusu sorma & 115 & 5.53 \\
& Görsel okuma sorusu sorma & 105 & 5.05 \\
& Söz sanatları sorusu sorma & 87 & 4.18 \\
& Düşünceyi geliştirme yolları sorusu sorma & 81 & 3.89 \\
& Anlatım biçimleri sorusu sorma & 69 & 3.31 \\
& Diğer konularda soru sorma & 30 & 1.44 \\
\hline Yazma becerisi & Hazırlanan etkinlikleri sunma & 49 & 2.35 \\
& Etkinlik oluşturma & 22 & 1.05 \\
& Materyal hazırlama & 1 & 0.04 \\
\hline Dinleme becerisi & Metinlere ulaşabilme & 50 & 2.38 \\
& Ölçme ve değerlendirme & 3 & 0.14 \\
& Etkinlik hazırlama & 3 & 0.14 \\
& Materyal geliştirme & 1 & 0.04 \\
\hline Konuşma becerisi & Örnek etkinlikleri paylaşma & 15 & 0.72 \\
& Konuşma metni hazırlama & 8 & 0.38 \\
& Etkinlik oluşturma & 6 & 0.28 \\
\hline Toplam & & 2.079 & 100 \\
\hline
\end{tabular}

Tablo 4'e bakıldığında temel dil beceri üzerine toplamda 2.079 paylaşım yapıldığı görülmüştür. 1.929 paylaşımla en fazla ele alınan beceri okuma olmuştur. Onu, yazma $(f=67)$ ve dinleme $(f=57)$ becerisi takip etmiştir. Konuşma ise 29 paylaşımla en az konuşulan beceri olarak belirlemiştir. 


\section{Okul İçi Etkinlikler}

Okul içi etkinlikler hakkındaki konuşulanların dağılımları Tablo 5'te görülmektedir:

Tablo 5.

Okul içi etkinliklere dair paylaşımların dağılımı

\begin{tabular}{|c|c|c|c|}
\hline \multicolumn{2}{|r|}{ Kodlar } & Sıklık & Yüzde \\
\hline \multirow[t]{3}{*}{ Etkinlikler } & Ders içi etkinlikler hazırlama & 277 & 28.27 \\
\hline & Okul geneli etkinlikler oluşturma & 85 & 8.67 \\
\hline & Kütüphane açma ve düzenleme & 29 & 2.96 \\
\hline \multirow{3}{*}{$\begin{array}{l}\text { Belirli gün ve } \\
\text { haftalar }\end{array}$} & Pano oluşturma & 336 & 34.31 \\
\hline & Yapılan çalışmaları paylaşma & 23 & 2.34 \\
\hline & Program hazırlama & 6 & 0.61 \\
\hline \multirow{5}{*}{$\begin{array}{l}\text { Tiyatro } \\
\text { çalışmaları }\end{array}$} & Tiyatro çalışmalarını paylaşma & 52 & 5.30 \\
\hline & Tiyatro metni bulabilme & 51 & 5.20 \\
\hline & Tiyatroya hazırlık sorunlarını çözme & 11 & 1.92 \\
\hline & Değerlendirme ölçeği hazırlama & 1 & 0.10 \\
\hline & Kulüp çalışmalarını düzenleme & 1 & 0.10 \\
\hline \multirow[t]{2}{*}{ Pano hazırlama } & Okuma için pano hazırlama & 52 & 5.31 \\
\hline & Ders panosu düzenleme & 43 & 4.39 \\
\hline \multirow[t]{3}{*}{ Değerler eğitimi } & Yapılan uygulamaları paylaşma & 8 & 0.81 \\
\hline & Pano hazırlama & 2 & 0.20 \\
\hline & Uygulama geliştirme & 1 & 0.10 \\
\hline \multicolumn{2}{|l|}{ Toplam } & 979 & 100 \\
\hline
\end{tabular}

Tablo 5'te okul içi etkinlikler hakkında 979 paylaşım yapıldığı görülmüştür. 391 paylaşımla etkinlikler ilk sırada yer almıştır. 276 paylaşımla belirli gün ve haftalar için düzenlenen çalışmalar ikinci sırada bulunmuştur. 11 paylaşımla değerler eğitimi okul içi etkinlik temasında en az konuşulan alt tema olmuştur.

\section{Kelime Öğretimi}

Türkçe öğretmenlerinin kelime öğretimi üzerine tartışmaları Tablo 6'da görülmektedir:

Tablo 6.

Kelime öğretimi çalışmalarının dağılımı

\begin{tabular}{|c|c|c|c|}
\hline \multicolumn{2}{|r|}{ Kodlar } & \multirow{2}{*}{$\begin{array}{l}\text { Sıklık } \\
255\end{array}$} & \multirow{2}{*}{$\begin{array}{l}\text { Yüzde } \\
40.32\end{array}$} \\
\hline Deyim ve atasözü & Deyim ve atasözü paylaşma & & \\
\hline \multirow[t]{2}{*}{ öğretimi } & Yapılan etkinlikleri paylaşma & 93 & 14.07 \\
\hline & Deyim ve atasözlerini anlatma & 16 & 2.52 \\
\hline \multirow[t]{3}{*}{ Kelime öğretimi } & Kelime örneklerini paylaşma & 207 & 32.74 \\
\hline & Kelime öğretimi çalışmaları yapma & 34 & 5.37 \\
\hline & Yapılan çalışmaları paylaşma & 27 & 4.74 \\
\hline Toplam & & 632 & 100 \\
\hline
\end{tabular}

Tablo 6 incelendiğinde kelime öğretimi çalışmaları için toplamda 632 paylaşım yapıldığı belirlenmiştir. Paylaşımlardan 364'ü atasözleri ve deyimler üzerineyken $268^{\prime}$ i kelime öğretimi hakkındadır.

\section{Mesleki Gelişim}

Mesleki gelişim için tartıştıkları hususların dağılımları incelenmiş, verilerin yüzde ve sıklık dağılımı Tablo 7'de görülmektedir: 
Türkçe Öğretmenlerinin Karşılaştıkları Sorunların, Sorunlara Yönelik Eleştiri ve Önerilerin Sosyal Medya Üzerinden İncelenmesi

Tablo 7.

Mesleki gelişim sağladıkları konuların dağılımı

\begin{tabular}{|c|c|c|c|}
\hline & Kodlar & Sıklık & Yüzde \\
\hline Mesleğe yönelik & Mesleki gelişim & 156 & 34.51 \\
\hline \multirow[t]{3}{*}{ sorunlar } & Atama ve tayin işlemleri & 84 & 18.58 \\
\hline & İş takvimi üzerine tartışma & 63 & 13.93 \\
\hline & İş yükünü tartışma & 38 & 8.40 \\
\hline Türkçe & Ders planı hazırlanması & 52 & 11.50 \\
\hline \multirow[t]{2}{*}{$\begin{array}{l}\text { Öğretim Programı } \\
\text { (TDÖP) }\end{array}$} & $\begin{array}{l}\text { Dil bilgisi konularının programda } \\
\text { sıralanması }\end{array}$ & 44 & 9.73 \\
\hline & Program değişikliği bilgilendirilmesi & 18 & 3.98 \\
\hline Toplam & & 452 & 100 \\
\hline
\end{tabular}

Tablo 7'de mesleki gelişim için 452 paylaşım yapıldığı belirlenmiştir. Paylaşımların 341'i mesleğe yönelik sorunlar hakkındayken 111'i TDÖP'e dairdir.

\section{Ölçme ve Değerlendirme}

Ölçme ve değerlendirme üzerinde konuşulanların dağılımları Tablo 8'de görülmektedir:

Tablo 8.

Ölçme ve değerlendirme üzerine konuşulanların dağılımı

\begin{tabular}{llll}
\hline & \multicolumn{1}{c}{ Kodlar } & Sıklık & Yüzde \\
\hline Okul sınavları & Örnek sınav paylaşma & 120 & 30.61 \\
& Sınav kâğıdı hazırlama & 30 & 7.64 \\
& Sınav tarihlerini belirleme & 2 & 0.51 \\
\hline Merkezi sınavlar & Sınavlardaki soruları tartışma & 46 & 11.73 \\
& Sistemdeki değişikleri tartışma & 42 & 10.71 \\
& Sınav sonuçlarını inceleme & 24 & 6.12 \\
& Başvuru koşullarını öğrenme & 23 & 5.86 \\
\hline Sözel mantık & Soru örneklerini çözme & 96 & 24.48 \\
& Kaynak bulma & 7 & 1.78 \\
& Ders içinde anlatma & 2 & 0.51 \\
\hline Toplam & & 392 & 100 \\
\hline
\end{tabular}

Tablo 8 incelendiğinde ölçme ve değerlendirme üzerine yapılan 392 paylaşımın 152'si okul sınavlarına aitken $105^{\prime}$ i sözel mantık sorularına dairdir.

\section{Ders Materyalleri}

Ders materyalleri açısından problem olan konuların dağılımları Tablo 9'da görülmektedir:

Tablo 9.

Ders materyalleri üzerine tartışılanların dağılımı

\begin{tabular}{llll}
\hline & \multicolumn{1}{c}{ Kodlar } & Sıklık & Yüzde \\
\hline Ders kitapları & Yazım ve noktalama yanlışları & 65 & 16.74 \\
& Etkinliklerin cevapları & 61 & 15.71 \\
& Metinlerin uygunluğu & 13 & 3.35 \\
& Etkinliklerin anlaşılırlığı & 12 & 3.08 \\
& Resim metin uyumu & 6 & 1.54 \\
& Ders ve çalışma kitabı uyumu & 4 & 1.03 \\
\hline Kitap & Tavsiye okuma listeleri & 87 & 22.42 \\
istekleri/tavsiyeleri & Alan bilgisine ait kaynak istekleri & 79 & 20.33 \\
\hline
\end{tabular}




\begin{tabular}{llll}
\hline & Sınıf yönetimine dair kitap istekleri & 41 & 10.56 \\
& Okuma kitabı listesi istekleri & 20 & 5.14 \\
\hline Toplam & & 388 & 100 \\
\hline
\end{tabular}

Tablo 9 incelendiğinde ders materyalleri üzerine 388 paylaşım yapılmıştır. Paylaşımların 227'si ders kitapları, 161'i kitap tavsiyeleri/istekleri hakkındadır.

\section{Projeler}

Projeler hakkında görüş alışverişlerinin dağılımı Tablo 10'da görülmektedir:

Tablo 10.

Projelerle ilgili çalışmaların dağımı

\begin{tabular}{llll}
\hline & \multicolumn{1}{c}{ Kodlar } & Sıklık & Yüzde \\
\hline TÜBiTAK projeleri & Yapılan proje çalışmalarını paylaşma & 136 & 54.4 \\
& Proje konusu belirleme & 46 & 18.4 \\
& Malzeme temin etme & 15 & 6 \\
& Hazırlama, başvuru ve kabul süreçlerini & 12 & 4.8 \\
& Öğrenme & & 8.8 \\
\hline Okul proje & Konu belirleme & 22 & 5.6 \\
ödevleri & Verilme koşullarını saptama & 14 & 2 \\
\hline Toplam & Değerlendirme ölçeği hazırlama & 5 & 100 \\
\hline
\end{tabular}

Tablo 10 incelendiğinde "Projeler" başlığında en fazla paylaşımın 209 paylaşım ile TÜBITAK projeleri, en az paylaşım ise 41 paylaşımla okul proje ödevleri hakkındadır.

\section{Tartışma ve Sonuç}

Görevdeki öğretmenlerin soru ve tartışmaları sahadan dönüt alma adına çok önemlidir. Sadece meslektaşları açısından değil akademisyenler, MEB'deki yöneticiler ve genel program tasarımcıları için de bu tarz bulgu ve dönütler oldukça mühimdir. Türkçe öğretmenlerinin öneri, eleştiri ve sorunlarının incelendiği çalışmanın bu bölümünde araştırma sonuçları tartışılacaktır.

\section{Dil Bilgisi ve Dil Bilgisi Öğretimi Temasına İlişkin Tartışma ve Sonuç}

Öğretmenler dil bilgisi konuları içinde en fazla görüş alışverişini "ekler ve kökler" için yapmıştır. Türkçenin ek çeşitliği bakımından zengin olması ve kelimelerin köklerini belirlemek için etimolojik tartışmaların meydana gelmesi sebebiyle bu sonuç ortaya çıkmış olabilir. En az tartışma ise "eğik çizgi" üzerine yapılmıştır. Öğretmenlerin en az noktalama işaretlerini ele alması konuyu çok iyi bilmelerinden mi konu hakkında çelişkiye düşürecek kısımlarının olmamasından mı yoksa ders sürecinde konuya pek fazla değinmediklerinden mi kaynaklandığı sorularını cevaplamak için öğretmenlerle görüşme yapılmadığından bu tip sorular araştırmanın amacı dışında bırakılmıştır. Buna karşın Atasoy'un (2010: 124), çalışmasında öğretmenlerin noktalama işaretlerine yeteri kadar ağırlık verilmediğini ifade etmiştir.

Dil bilgisi genelinde olmakla birlikte bu paylaşımların büyük bir kısmı Türkçe öğretmenlerinin ek ve kök ayırımı, anlatım bozukluğu, cümlenin ögeleri, fiilde çatı, fiilimsi, kelime türleri, sözcükte yapı ve ek fiil gibi nerdeyse tüm dil bilgisi konularının öğretiminde sıklıkla çelişkiye düştükleri, tam manası ile karar veremedikleri konuları çözüme kavuşturmak amacı taşıdıkları tespit edilmiştir. Öğretmenler arasındaki bir danışma merkezine yahut başvuru kaynağına ulaşmak dil bilgisi öğretimi için en büyük sorundur. Bu noktada sosyal medya bir çeşit öğretmen grupları aracılığıyla "danışma merkezi"ne ya da başvuru kaynağına dönüşmüştür. Paylaşımların altındaki tartışmalara bakıldığında öğretmenler kendi aralarında uzlaşamadıkları noktalarda ÖSYM, MEB ve TDK'nin fikirlerine ve alan uzmanlarına başvurmuşlar. Fakat kurumlar arasında uyum olmaması ve alan uzmanlarının aynı konu hakkında 
Türkçe Öğretmenlerinin Karşılaştıkları Sorunların, Sorunlara Yönelik Eleştiri ve Önerilerin Sosyal Medya Üzerinden İncelenmesi

farklı görüşlere sahip olması öğretmenleri ikiliğe düşürmüştür. Araştırmanın bu sonucunun alanyazındaki çalışmalarla örtüştüğü görülmüştür (Erdem, 2007: 155; Önal, 2010: 149; Güven, 2011: 4; Bulut, 2014: 43). İlköğretim ve ortaöğretim kademelerinde dil bilgisi öğretimindeki karmaşayı ortadan kaldırmak amacıyla MEB tarafından ortak bir dil bilgisi öğretimi kitabı oluşturulmalıdır.

Dil bilgisi öğretiminde konu anlatımı için öğretmenler meslektaşlarına danışma ve onların fikir ve deneyimlerinden yararlanma gereksinimi duymuşlar $(f=215)$. Bu dil bilgisi öğretiminde tespit edilen ikinci sorun olmuştur. Öğretmenler dil bilgisi öğretiminde çalışma sayfası düzenleme $(f=80)$, materyal geliştirme $(f=65)$ ve eğitsel oyun hazırlama $(f=43)$ üzere deneyimli öğretmenlere danışmışlar. Bu noktada öğretmenler materyal, oyun ve etkinliğe ihtiyaç hissettikleri görülmüştür. Veenman (1984: 143) araştırmasında öğretmenlerin temel sorunlarından birinin ders materyalleri ve malzemeleri ile ilgili olduğunu tespiti, bu araştırmayla aynı düzlemdedir.

Dil bilgisi öğretiminde ders sürecinde ele alınacak kavramların tespit edilmesi en az problem oluşturan unsur olarak belirlenmiştir ( $f=31$ ). Göçer ve Aslan (2019: 298), dil bilgisi öğretiminde ortaya çıkan sorunlarda öğretmenlerin payı olduğu kadar TDÖP'ün de etkisi olduğu sonucu bu çalışma ile benzer niteliktedir. Alyılmaz (2010: 731) ise dil bilgisi kazanımlarının genel ifadelerden oluştuğunu, açıklamaların açık ve daha somut olmasının uygun olacağı fikri de bu araştırma sonucu ile aynı yöndedir.

\section{Temel Dil Becerilerine ilişkin Tartışma ve Sonuç}

Türkçe öğretmenlerinin problem yaşadıkları ikinci konu dil becerilerini geliştirmekle ilgilidir. Dil becerileri ile ilgili sırasıyla "okuma" ( $f=1.929)$, "yazma" ( $f=67)$, "dinleme" ( $f=57$ ) ve "konuşma" ( $f=29)$ üzerine konuşulmuştur. Ünsal'ın (2019: 161) çalışmasındaki Türkçe öğretmenlerinin ders içerisinde temel dil becerilerine yer ver verme miktarıyla ilgili araştırma sonucu ile bu bulgu örtüşmüştür. Öğretmenlerin en az konuşma becerisini tartışması konuşma becerisinin geliştirilmesine hâkim olmalarından mı derslerinde çok fazla yer vermemelerinden mi kaynaklandığı sorularını cevaplamak için öğretmenlerle görüşme yapılmadığından bu tip sorular araştırmanın amacı dışında bırakılmıştır.

Okuma becerisi üzerine tartışmalar paragrafta anlam ( $f=655)$, sözcükte anlam ( $f=464)$, cümlede anlam ( $f=320)$, metin türleri $(f=115)$, görsel okuma $(f=105)$, söz sanatları $(f=87)$, düşünceyi geliştirme yolları $(f=81)$, anlatım biçimleri $(f=69)$ ve diğer $(f=30)$ şeklinde sıralanmaktadır. En çok paragrafta anlam, sözcükte anlam ve cümlede anlam gibi okuduğunu anlamayla konular okuma becerisinde problem teşkil etmiştir. Merkezi sınavların daha çok bu sorulardan oluşması ayrıca öğretmenlerin de bu tarz sorularla sıkça karşılaşması bu sonucu ortaya çıkarmış olabilir.

Yazma becerisini geliştirilirken uygulanan etkinlikleri $(f=49)$ paylaştıkları kadar etkinlik oluşturmak için de $(f=22)$ fikre ihtiyaç duydukları görülmüştür. Öğretmenler yazma becerisine yönelik hazırladıkları etkinlikleri paylaşmak için heveslidir. Fakat etkinlik üretme konusunda sıkıntı çekmişlerdir. Materyal hazırlamaya $(f=1)$ ihtiyaç duyulmuş, bu noktada diğer öğretmenlerden destek almak istemişlerdir.

Dinleme becerisiyle ilgili en büyük sorun metinlere ulaşabilmek üzerinedir $(f=50)$. Öğretmenler, dinleme metinlerine ulaşmak için diğer öğretmenlere başvurmuşlardır. Güven (2011: 130) ve Keray Dinçel (2018: 119) araştırmalarında teknolojik yetersizlikler nedeniyle öğretmenlerin kaldırılmadan önce öğretmen kılavuz kitaplarından metinlere ulaştıklarını tespit etmiştir. Öğretmen kılavuz kitaplarında dinleme metinlerinin bulunması onlara kolaylık sağlamış olsa da günümüzde öğretmen kılavuz kitapları kullanılmamaktadır. Bunun haricinde dinleme becerisini geliştirmek için etkinlik oluşturmak ( $f=3$ ), ölçme ve değerlendirme araçları $(f=3)$ ve materyal geliştirmek $(f=1)$ üzere diğer öğretmenlerden fikir almak istemişler.

Temel dil becerileri içerisinde en az ele alınan beceri konuşmadır $(\mathrm{f}=29)$. Dil becerilerinin bütününe bakıldığında bu miktar oldukça düşüktür. Konuşma becerisi içerisinde öğretmenler en çok yaptıkları etkinlikleri paylaşmak istemişler $(f=15)$. Nitekim Temizyürek (2007: 129) ve Ünsal (2019: 161) konuşma becerisi için bazı uygulamalar yapıldığını fakat bu uygulamaların yetersiz olduğu sonuçları araştırmanın bulguları ile benzedir. Bununla beraber öğretmenler belirli gün ve haftalarda kullanılmak üzere konuşma metinlerine ulaşmak istemişler ve zümre grubuna başvurmuşlar. 


\section{Okul İçi Etkinlikler Temasına ilişskin Tartışma Sonuç}

Okul genelinde, sınıf içerisinde öğretmenler pek çok uygulama yapmışlar ve çalışmalarını zümreleri ile paylaştıkları görülmüştür. Türkçe öğretmenlerinin belirli gün ve haftalar için okul ve sınıf içerisinde yer alan panoları, törenler için hazırlanan programları, yazarların doğum ve ölüm yıl dönümü çalışmaları ile törenler için düzenlenen etkinlikleri diğer öğretmenlerle paylaştıkları tespit edilmiştir. İskender, Yiğit ve Bektaş (2015: 324) ve Şengül ve Alkaya (2016: 105) araştırmalarında öğretmenlerin belirli gün ve haftalar için program hazırlama, katılım sağlama konusunda kendilerini yeterli bulduklarını saptaması bu araştırma sonucu ile uyuşmaktadır.

Uyguladıkları tiyatro çalışmalarını $(f=52)$ paylaşmak istemişler. Bu alt temada en büyük problem tiyatro metinleri belirlemek olmuştur $(f=51)$. Tiyatro metni seçmek için diğer öğretmenlere danışmaya intiyacı duyulmuştur. Tiyatroya hazırlık sorunları $(f=11)$, ölçek hazırlama $(f=1)$, tiyatro kulübünde yapılacaklar $(f=1)$ tiyatro alt temasında tartışılan diğer noktalardır. Öğretmenler karşılaştıkları problemleri çözüme kavuşturmak için diğer öğretmenlerden fikir almışlar.

Değerler eğitiminde yapılan uygulamaları paylaşma $(f=8)$, pano hazırlama $(f=2)$ ve neler yapılabileceğini sorma $(f=1)$ noktaları konuşulmuş ve okul içi etkinlikler temasında en az ele alınan alt tema belirlenmiştir ( $f=11)$. Elbir ve Bağcı (2013: 242) araştırmasında değerler eğitiminin öğretmenler tarafından pek fazla benimsenemediği ve bu konuda öğretmenlere farklı uygulamalarla bilgilendirilmesinin uygun olduğu söylemiştir. Bu sonuç, bu araştırmanın sonucuyla aynı doğrultudadır.

\section{Kelime Öğretimi Temasına iliş̧kin Tartışma Sonuç}

Türkçe öğretmenleri atasözleri ve deyim ( $f=364$ ) öğretimine kelime ( $f=268)$ öğretimine göre daha fazla ağırlık vermişler. Deyim ve atasözü ve kelime örnekleri paylaştıkları görülmüştür $(f=462)$. Öğretmenler, kelime öğretimi çalışmaları yürütürken kendi kelime hazineleri için paylaşımlar yapmış ve zaman zaman bu paylaşımların altında tartışmalar yaşanmıştır.

Öğretmenlerin önemli bir kısmı kelime öğretimi için çeşitli etkinlikler uyguladığı $(f=120)$ ve bunları paylaşmak istedikleri belirlenmiştir. Bazı öğretmenlerin de kelime öğretimi için uygulama arayışında oldukları saptanmıştır $(f=50)$. Buna göre öğretmenlerin büyük çoğunluğunun kelime öğretimi için kendi çalışmalarını kendilerini gerçekleştirdiği ve bu anlamda yeterli olduğu söylenebilir. Hazırlanan çalışmaların yer aldığı ve uygulama örnekleri istenilen paylaşımlarda öğretmenlerin kelime öğretimi için farklı yollar izlediği görülmüştür. Alan yazında öğretmenlerin kelime öğretimi için ortak bir yol izlemediklerini buna karşın izlemeleri gerektiğini belirtilmiş, bu çalışmalar ile araştırmanın sonucu benzerdir (Karadağ ve Kurudayıoğlu, 2010: 435; Berne ve Blachowicz, 2011: 321-322; Akyüz Aru ve Ertem, 2014: 618).

\section{Mesleki Gelişim Temasına ílişkin Tartışma Sonuç}

Mesleğe yönelik sorunlar başlığında meslek hayatlarında karşılaştıkları sorunlar, atama ve tayin işlemleri, iş yükü için tecrübeli öğretmenlerin fikirlerine gereksinim duymuşlardır. Buna ek olarak iş takvimi hakkında bilgilendirici paylaşımlar yapmışlar. Türkçe öğretmenlerinin ders planı hazırlamak üzere ve örnek planlara ulaşma noktasında diğer öğretmenlere danışma ihtiyacında olmuşlar. Ayrıca TDÖP ile ilgili görüşlerini, kafalarında soru işareti oluşturan unsurları tartışmıslardır.

\section{Ölçme ve Değerlendirme Temasına iliş̧kin Tartışma Sonuç}

Ölçme ve değerlendirme ana temasında en fazla okul sınavları ( $f=152)$ konuşulmuştur. Türkçe öğretmenlerinin büyük bir bölümü okulda yapılan sınavlarda kendi sınavlarını hazırlamış $(f=120)$, bazen de sınav örnekleri de istemişler $(f=30)$. Bu sonuca bakıldığında öğretmenlerin ölçme ve değerlendirme açısından yeterli oldukları söylenebilir. Çakan (2004: 108-109) ve Veenman'ın (1984: 143) öğretmenlerin önemli bir bölümünün ölçme ve değerlendirme noktasında yetersiz buldukları sonucu ile uyuşmamıştır. Türkçe öğretmenlerinin sınav tarihlerini belirleme noktalarında problem yaşadıkları belirlenmiştir $(f=2)$. Öğretmenlerin bu sorunun cevabı yönetmelikte yer almaktadır.

Eğitim öğretim sürecinde okullarda yapılan sınavlar kadar sık olmasa da liseye geçiş için yapılan sınavların yanı sıra PISA gibi uluslararası merkezi sınavlar da yapılmaktadır. Merkezi sınavlar 
Türkçe Öğretmenlerinin Karşılaştıkları Sorunların, Sorunlara Yönelik Eleştiri ve Önerilerin Sosyal Medya Üzerinden İncelenmesi

ölçme ve değerlendirme temasındaki ikinci büyük sorun olmuştur ( $f=135)$. Öğretmenler sınavlarda yer alan bazı soruların cevabında kendi aralarında uzlaşamamışlar $(f=46)$, bu durum merkezi sınavlarda en çok tartışılan unsur olmuştur. Sorular hakkında farklı görüş bildirilmesi ya da soruların yeterince açık olmaması bu sonucu ortaya çıkarmış olabilir. Sınav sonuçlarını değerlendirmişlerdir $(f=24)$ ve sınav sisteminde meydana gelen değişiklikler $(f=42)$ ve sınavlara başvuru ve koşulları $(f=23)$ üzerine diğer öğretmenleri bilgilendirmek için paylaşım yapmışlar. Öğretmenlerin sitemdeki güncellemelerden haberdar etme, diğer öğretmenlerle görüş alışverişi açısından sosyal medyadan yararlandıkları tespit edilmiştir.

Merkezi sınavlarda yer alan sözel mantık soruları üzerine soru örneklerini çözme, kaynaklara ulaşma ve ders içinde anlatma kodları konuşulmuştur ( $f=105)$, bu ölçme ve değerlendirme temasında en az ele alınan alt temadır. Öğretmenlerin sözel mantık soruları çözememeleri bu alt temadaki en büyük problemi meydana getirmiştir $(f=96)$. Bununla birlikte konuyla ilgili yardımcı kaynak tavsiyesi istedikleri belirlenmiştir $(\mathrm{f}=7)$. Yardımcı kaynak istekleri ile öğretmenlerin bu konuda kendilerini geliştirmek istedikleri şeklinde yorumlanabilir.

Sözel mantık sorularına ders saati içinde yer verilmesi gerekliliği öğretmenler tarafından tartışılmış $(\mathrm{f}=2)$, bir kısmı ders saati içinde değinilmesi gerektiğini düşünürken bir kısmı yer değinilmemesi gerektiğini ifade etmiştir. Bu durum uygulamada öğretmenler arasında ortak bir tutum olmadığını ve öğrencilerin konu hakkında farklı bilgi düzeylerine sahip olmalarına neden olmuştur.

\section{Ders Materyalleri Temasına i̇lişkin Tartışma ve Sonuç}

Ders materyalleri açısından "ders kitapları" ( $f=227)$ ve "kitap tavsiyeleri/istekleri" ( $f=161)$ konuları üzerine konuşulmuştur. Ders kitapları hakkındaki en büyük sorunun yazım ve noktalama yanlışları üzerinedir $(f=65)$. Öğretmenler, sıklıkla ders kitaplarında yazım kurallarına uyulmadığı ve noktalama işaretlerinin doğru kullanılmadığını ifade etmişler. Çiçek ve Alcellat (2014: 120-126) araştırmasında Türkçe ders kitaplarında dikkatsizlikten kaynaklandığını bazı yazım yanlışlarııın olduğunu ancak bu durumun kabul edilebilir olmadığını görüşü bu çalışmayı desteklemiștir.

Öğretmenler bazı etkinliklerin cevapları konusunda ortak bir kararda bulunamamaları ders kitaplarındaki ikinci problemdir ( $f=61$ ). Bu durum öğretmenlerin dil bilgisi kurallarını, metinleri ya da etkinlikleri farklı yorumları ile meydana gelmiş olabilir.

Metinlerin öğrenci seviyesine uygunluğu noktasında ders kitapları yeterli bulunmamıştır $(f=13)$. Yapılan araştırmalarda da ders kitaplarındaki metinlerin uzun, öğrenci seviyesinin üzerinde, cümle yapıları ve kelime seçimi dili kullanma bakımından uygun olmadığı, metin türleri ve çeşitliği yetersiz olduğu sonuçları öğretmenlerin problemlerini destekler niteliktedir (Alyılmaz, 2010: 735-736; Güven, 2011: 130; Güleç ve Demirtaş, 2012: 74; Diker Coşkun, 2013: 37-39).

Ders kitaplarındaki birtakım etkinliklerin öğrenci seviyesine uygunluğu tartışılmış ve uygun olmadığını dile getirilmiştir $(f=12)$. Yapılan araştırmalar da etkinliklerin öğrenci seviyesine uygun olmadığı, onların intiyaçlarına cevap verme konusunda yetersiz olduğu ve geliştirilmesi gerektiği görüşü bu araştırma sonucunu ile uyuşmaktadır (Çiçek ve Alcellat, 2014: 126; Çevik ve Güneş, 2017: 272). Aynı zamanda etkinliklerde yönlendirici ifade ve anlaşıırlık bakımından yeterince açık olmadığı ifade edilmiştir. Alyılmaz'ın (2010: 736-737) çalışma sonucuyla bu durum örtüşmüştür.

Öğretmenler, ders kitaplarındaki bazı metinleri görsel tasarım açısından yeterli bulmadıklarını ifade etmişler $(f=6)$. Bu, ders kitaplarında en az görüş bildirilen husustur. Güleç ve Demirtaş'ın (2012: 74) Türkçe ders kitaplarının görsel tasarım bakımından geliştirilmesi görüşü bu çalışma ile aynı yöndedir.

Kitap tavsiyeleri/istekleri alt temasında bazı öğretmenler kendi ölçütlerine göre oluşturdukları okuma kitabı tavsiyelerini paylaşırken ( $f=87$ ), küçük bir kısmı da tavsiyelere ihtiyaç duymuştur ( $f=20$ ). Maltepe'nin (2009: 411) Türkçe öğretmeni adaylarının çocuk kitabı seçme konusunda problem yaşadıkları sonucu bu araştırma ile tam olarak örtüşmemektedir.

Öğretmenler, alan bilgisi $(f=79)$ ve sınıf yönetimine $(f=41)$ dair diğer öğretmenlerden farklı zamanlarda kitap tavsiyeleri istemeleri kendilerini bu konuda geliştirmeye hevesli olduklarına yorumlanabilir. Arıcı (2015: 12-13) çalışmasında Türkçe öğretmenleri ve öğretmen adaylarına akademik, alan bilgisi, genel kültür, pedagojik olarak okumaları gereken kitapları belirlemiştir. 


\section{Projeler Temasına ilişkin Tartışma ve Sonuç}

Türkçe öğretmenleri tarafından en az ele alınan tema projelerdir. Bu temada TÜBiTAK Bilim Fuarı $(f=209)$ ve okul proje ödevleri $(f=41)$ alt temaları ele alınmıştır. Öğretmenlerin bilim fuarı için hazırladıkları projeleri meslektaşları ile paylaştıkları tespit edilmiştir ( $f=136)$. TÜBITAK projeleriyle ilgili en büyük problem proje konusu bulunamamasıdır $(f=46)$. Öğretmenler, farklı zaman dilimlerinde bilim fuarı için proje konusu bulmak üzerine paylaşım yapmışlar. Yorumlara göz atıldığında "Göktürk Yazıtları", "yöresel kelimeler", "kitap kumbarası", "kelime oyunları", "deyimleri üç boyutlu hazırlama" gibi benzer fikirlerden sıklıkla bahsettikleri görülmüştür. Bu noktada Ö2 "...Düşünelim beraber yeni konular için." ifadesiyle yeni proje konularına ihtiyaç duyulduğunu dile getirmiştir.

TÜBITAK Bilim Fuarı için en az görüş alışverişi yapılan nokta proje hazırlanışı, başvuru ve kabul koşullarıdır ( $\mathrm{f}=12$ ). Örneğin grup üyelerinden Ö3 “...Kısaca bilgi verebilir misiniz? Tek proje mi yapıyorsunuz?" şeklindeki paylaşımıyla proje süreci ve şartlarına dair bir soru yöneltmiştir. Öğretmenler bilim fuarıyla ilgili yeterli donanıma sahip olmadıkları saptanmıştır. 2019 TÜBITAK 8. Bilim Fuarları Kılavuzu'nda gerekli bilgiler yer almaktadır (TÜBITAK, 2019). Okuyucu'nun (2019: 213) öğretmenlerin TÜBITAK Bilim Fuarı hakkında yeterli olmadığı tespiti araştırmanın sonucu ile örtüşmüştür.

Okul proje ödevleri hakkında en çok konu belirleme noktasında fikirlere ihtiyaç duyulmuştur $(\mathrm{f}=22)$. Bu tür paylaşımların altına öğretmenler kendi fikirlerinden ve sistemlerinden bahsetmişlerdir. Araştırma sonucunda her öğretmenin farklı farklı proje konusu belirledikleri, aralarında ortaklık söz konusu olmadığı görülmüştür. Arslan (2013: 21) çalışmasında öğretmenler arasında proje ödevi konusu belirleme ve değerlendirme için ortak bir tutum sergilemedikleri sonucuna ulaşmıştır. Bu açıdan araştırma Arslan (2013: 21)'ın çalışmasıyla benzer sonuca ulaşmıştır.

Okuldaki proje ödevlerinin verilme, hazırlanma koşulları konusunda öğretmenlerin fikir ve desteğe intiyaç duymuşlar. Hâlbuki MEB'in yönetmeliğinde tüm bu soruların cevapları vardır. Öğretmenler yönetmelikleri incelemek yerine sürekli kullandıkları sosyal medya grubuna sormanın daha kolay gelmiş olabilir.

Proje ödevlerinin ölçme ve değerlendirmesi de bir sorun $(f=5)$ ortaya çıkarmıştır. Öğretmenlerin proje ödevi değerlendirme ölçeğini gruptan hazır olarak kullandıkları tespit edilmiştir. Değerlendirme ölçeği hazırlamakta zorlanıyor oldukları veya hazır bir ölçeği kullanmanın daha kolay olduğu düşünülebilir.

\section{Öneriler}

1. Öğretmenlere dil bilgisi öğretimi, temel dil becerileri ve kelime öğretimi için işlevsel ve uygulanabilir materyal, etkinlik, malzeme ve uygulama tasarımları hazırlanmalıdır.

2. Sosyal medya üzerinden öğretmen grupları düzenli taranarak elde edilen bilgilerin hizmet öncesi ve hizmet içi eğitimlerinin işlevsel olarak planlanmasında etkin kullanılmalıdır.

3. Türkçe öğretmenlerinin yanı sıra tüm branştan öğretmenlerin görüş, öneri ve sorunları zaman zaman toplanarak bu verilerden hareketle eğitim öğretim sistemi üzerinde güncellemeler yapılmalıdır.

4. 2018 yılından sonraki yıllarda yine sosyal medya aracılığıyla Türkçe öğretmenlerinin sorunlarının incelenerek bu iki araştırma verilerinin karşılaştırmalı analizinin yapılmalıdır. Böylece sorunların çözümü, değişkenliği gibi konuların da tartışılabileceği bir çalışma ortaya çıkabilir.

\section{Kaynaklar}

Afşin, Z. (2019). Sosyal Bilgiler Öğretmenlerine Yönelik Bir Facebook Grubunun ve Bu Gruba iliş̧kin Öğretmen Görüşlerinin Incelenmesi. Yüksek Lisans Tezi, Niğde Ömer Halisdemir Üniversitesi Eğitim Bilimleri Enstitüsü, Niğde.

Akyüz Aru, S. ve Ertem I. S, (2014). Türkçe Ders Kitaplarında Kelime Hazinesini Geliştirmeye Yönelik Planlamanın İncelenmesi. Turkish Studies, 9(3), 675-694.

Alabdulkareem, S. A. (2015). Exploring The Use and The Impacts Of Social Media On Teaching and Learning Science in Saudi. Procedia - Social and Behavioral Sciences, 182, 213-224. 
Türkçe Öğretmenlerinin Karşılaştıkları Sorunların, Sorunlara Yönelik Eleştiri ve Önerilerin Sosyal Medya Üzerinden İncelenmesi

Alyılmaz, C. (2010). Türkçe Öğretiminin Sorunları. Turkish Studies, 5(3), 728-749.

Arıcı, A. F. (2015). Türkçe Öğretmenleri / Öğretmen Adayları Ne Okumalı? -Bir "Okuma Listesi” Önerisi. Hacettepe Üniversitesi Eğitim Fakültesi Dergisi, 30(3), 1-15.

Arkan, A. ve Yünter, S. (2018). Eğitim İçin Sosyal Ağlar. Seta Perspektif, 217, 1-6.

Arslan, A. (2013). Türkçe Öğretmenlerinin Proje ve Performans Ödevleri ile İlgili Görüşlerinin Değerlendirilmesi. Dil ve Edebiyat Eğitimi Dergisi, 2(6), 11-22.

Atasoy, F. O. (2010). Türkçede Noktalama İşaretleri İle İlgili Sorunlar. III. Uluslararası Dünya Dili Türkçe Sempozyumu (16-18 Aralık 2010 İzmir).

Başer, A. (2014). Sosyal Medya Kullanıcılarının Kişilik Özellikleri, Kullanım ve Motivasyonlarının Sosyal Medya Reklamlarına Yönelik Genel Tutumları Üzerindeki Rolü: Facebook Üzerine Bir Uygulama. Doktora Tezi, Marmara Üniversitesi, Sosyal Bilimler Enstitüsü, İstanbul.

Berne, J. I. ve Blachowicz, C. L. Z. (2008). What Reading Teachers Say About Vocabulary Instruction: Voices From The Classroom . The Reading Teacher International Literacy Association, 62(4), 314-323.

Boyd, D. M. ve Ellison, N. B. (2007). Social Network Sites: Definition, History, and Scholarship. Journal of Computer-Mediated Communication, 13(1), 210-230.

Bulut, M. (2014). Dil Bilgisi Öğretiminde Yaşanan Kavram Kargaşasının Türkçe Öğretimine Etkisi, Turkish Studies-International Periodical For The Languages, Literature And History Of Turkish Or Turkic, 9(12), 43-55.

Coşkun, E., Gelen, İ. ve Kan, M. O. (2009). Türkçe Derslerindeki Performans Ödevleri Konusunda Öğretmen ve Öğrenci Görüşlerinin Değerlendirilmesi. Mustafa Kemal Üniversitesi Sosyal Bilimler Enstitüsü Dergisi, 6(11), 22-55.

Çakan, M. (2004). Öğretmenlerin Ölçme-Değerlendirme Uygulamaları ve Yeterlik Düzeyleri: illk ve Ortaöğretim. Ankara Üniversitesi Eğitim Bilimleri Fakültesi Dergisi, 37(2), 99-114.

Çarkıt, C. (2019). Ortaokul Okuma Becerileri Dersine Yönelik Öğretmenlerin Görüş ve Uygulamaları. Ana Dili Eğitimi Dergisi, 7(4), 841-856.

Çevik, A. ve Güneş, F. (2017). Türkçe Ders Kitaplarındaki Etkinliklerin İncelenmesi. Ana Dili Eğitimi Dergisi, 5(2), 272-286.

Çiçek, M. ve Alcellat, N. (2014). İlköğretim Türkçe Dersi Kitaplarındaki Türkçe Yanlışları ve Eksiklikler Üzerine Bir İnceleme. Ana Dili Eğitimi Dergisi, 2(4), 120-134.

Demir, C. (2018). Okullarımızda Yazım Eğitimi ve Sorunları Üzerine. Afyon Kocatepe Üniversitesi Sosyal Bilimler Dergisi, 20(3), 121-135.

Deniz, İ. D. (2016). Öğretmen Mesleki Gelişim Aracı Olarak Bir Facebook Grubunun Incelenmesi. Yüksek Lisans Tezi, Gaziantep Üniversitesi, Eğitim Bilimleri Enstitüsü, Gaziantep.

Diker Coşkun, Y. (2013). Türkçe Ders Kitaplarının PISA Sınavı Okuma Ölçütleri Açısından İncelenmesi. Mehmet Akif Ersoy Üniversitesi Eğitim Fakültesi Dergisi, 26, 22-43.

Elbir, B. ve Bağcı, C. (2013). Değerler Eğitimi Üzerine Yapılmış Lisansüstü Düzeyindeki Çalışmaların Değerlendirilmesi. Turkish Studies, 8(1), 1321-1333.

Erdem, İ. (2007). Ilköğretim II. Kademede Dil Bilgisi Öğretiminin Sorunları Üzerine Bir Araştırma. Doktora Tezi, Gazi Üniversitesi, Eğitim Bilimleri Enstitüsü, Ankara.

Ergüney, T. (2019). Ortaokul Matematik Öğretmenlerinden Oluşan Bir Facebook Zümre Grubu ile Öğretmenlere Sunulan Desteğin Matematiği Öğretme Bilgisi Bağlamında incelenmesi. Yüksek Lisans Tezi, Trabzon Üniversitesi, Lisansüstü Eğitim Enstitüsü, Trabzon.

Esen, Y. D. Temel, F. ve Demir, E. (2017). Türkiye' deki Öğretmenlerin Karşılaştıkları Mesleki Sorunların İkili Karşılaştırma Yöntemi İle Ölçeklenmesi. Eğitimde ve Psikolojide Ölçme ve Değerlendirme Dergisi. 8(1), 47-62.

Geiger, T. ve Pivovarova, M. (2018). Çalışma koşullarının öğretmen tutmaya etkisi, Öğretmenler ve Öğretim, 24(6), 604-625.

Göçer, A. ve Arslan, S. (2019). Ortaokulda Gerçekleştirilen Dil Bilgisi Öğretimi Durumunun Öğretmen Görüşlerine Göre Değerlendirilmesi. Iğdır Üniversitesi Sosyal Bilimler Dergisi, 18, 297-326.

Gülbahar, Y. Kalelioğlu, F. ve Madran, R. O. (2010). Sosyal Ağların Eğitim Amaçlı Kullanımı. XV. Türkiye'de İnternet Konferansı, İstanbul: İstanbul Teknik Üniversitesi. 
Güleç, ì. ve Demirtaş, T. (2012). İlköğretim 8. Sınıf Ana Dili Ders Kitapları Üzerine Karşılaştırmalı Bir Çalışma: Türkiye-Amerika Birleşik Devletleri Örneği. Sakarya University Journal of Education, 2(1), 74-91.

Güven, A. Z. (2011). Illköğretim II. Kademe Türkçe Dersi Öğretim Programına İlişkin Öğretmen Görüşleri. Buca Eğitim Fakültesi Dergisi, 29, 121-133.

Hooftman, W. E. Mars, G. M. J. Janssen, B., Vroomee, E. M. M. ve Bossche ve S. N. J. Van den (2015). Nationale Enquête Arbeidsomstandigheden 2014. Methodologie en globale resultaten (National Working Conditions Survey 2014. Methodology and Overall Results).

Ingersoll, R. M. ve Strong, M. (2011). The Impact of İnduction And Mentoring Programs For Beginning Teachers A Critical Review of The Research. Review of Educational Research, 81 (2), 201233.

İskender, H. Yiğit, F. ve Bektaş, R. (2015). Türkçe Öğretmenlerinin Özel Alan Yeterliklerine Yönelik Görüşlerinin Çeşitli Değişkenler Açısından İncelenmesi. Uluslararası Türkçe Edebiyat Kültür Eğitim Dergisi, 4(1), 305-327.

Karadağ Ö.ve Kurudayıoğlu, M. (2010). 2005 Türkçe Programına Göre Hazırlanmış İlköğretim Birinci Kademe Türkçe Ders Kitaplarının Kelime Hazinesi. Türklük Bilimi Araştırmaları, 27, 423-436.

Keray Dinçel, B. (2018). Ortaokul Öğrencilerinin Türkçe Dersinde Yaşadıkları Dinleme Sorunları ve Sorunların Çözümüne Yönelik Beklentileri. Uluslararası Türkçe Edebiyat Kültür Eğitim Dergisi, 7(4), 2551-2571.

Kozikoğlu, I.., ve Senemoğlu, N. (2018). Mesleğe Yeni Başlayan Öğretmenlerin Karşılaştıkları Güçlükler: Nitel Bir Çözümleme. Eğitimde Nitel Araştırmalar Dergisi, 6(3), 341-371.

Long, J. S., McKenzie-Robblee, S., Schaefer, L., Steeves, P., Wnuk, S., Pinnegar ve Clandinin, D. J. (2012). Literature Review on Induction and Mentoring Related to Early Career Teacher Attrition and Retention. Mentoring \& Tutoring: Partnership in Learning, 20(1), 7-26.

Maltepe, S. (2009). Türkçe Öğretmeni Adaylarının Çocuk Edebiyatı Ürünlerini Seçebilme Yeterlilikleri. Balıkesir Üniversitesi Sosyal Bilimler Enstitüsü Dergisi, 12(21), 398-412.

Mayfıeld, A. (2008). What is Social Media. E-Book, Erişim Tarihi: 19.03.2020, What_is_Social_Media_ìcrossing_Ebook.Pdf.

Menteşe, M. (2013). Sosyal Medya Ortam ve Araçlarının Eğitimde Kullanımına İlişkin Okul Yöneticilerinin ve Öğretmenlerin Görüşleri. Yüksek Lisans Tezi, Hacettepe Üniversitesi, Sosyal Bilimler Enstitüsü, Ankara.

Miles, M. B. ve Huberman, A. M. (1994). Qualitative Data Analysis. Usa: Sage Publications.

Okuyucu, M.A. (2019). 4006-Tübitak Bilim Fuarına İlişkin Öğretmen ve Öğrenci Görüşleri. International Journal of Social Sciences and Education Research, 5(2), 202-218.

Önal, M. E. (2010). Türkçe Öğretmenlerinin IIlköğretim II. Kademede Gerçekleştirilen Dil Bilgisi Öğretimi Hakkındaki Görüşleri (Kırıkkale il Örneği). Yüksek Lisans Tezi, Kırıkkale Üniversitesi, Sosyal Bilimler Enstitüsü, Kırıkkale.

Öztürk, M. F. ve Talas, M. (2015). Sosyal Medya ve Eğitim Etkileşimi. Journal of World of Turks, 7(1). 101-119.

Preeti, M. (2009). Use of Social Networking in A Linguistically and Culturally Rich India. The International Information, 41(3), 129-136.

Sarsar, F. Başbay M. ve Başbay, A. (2015). Öğrenme-Öğretme Sürecinde Sosyal Medya Kullanımı. Mersin Üniversitesi Eğitim Fakültesi Dergisi, 11(2), 418-431.

Seferoğlu, S. S. (2001). Sınıf Öğretmenlerinin Kendi Meslekî Gelişimleriyle Ilgili Görüşleri, Beklentileri ve Önerileri. Milli Eğitim, (149), 12-18.

Siddiqui, S. ve Singh, T. (2016). Social Media İts Impact With Positive and Negative Aspects. International Journal of Computer Applications Technology and Research, 5(2), 71-75.

Şengül, K. ve Alkaya, E. (2016). Türkçe Öğretmenlerinin Özel Alan Yeterlikleri: Bir Durum Belirleme Çalışması. Ankara Üniversitesi Eğitim Bilimleri Fakültesi Dergisi, 49(2), 87-108.

Temizyürek, F. (2007). Ilköğretim İkinci Kademede Konuşma Becerisinin Geliştirilmesi. Ankara Üniversitesi Eğitim Bilimleri Fakültesi Dergisi, 40(2), 113-131. 
Türkçe Öğretmenlerinin Karşılaştıkları Sorunların, Sorunlara Yönelik Eleştiri ve Önerilerin Sosyal Medya Üzerinden İncelenmesi

Türkiye Bilimsel ve Teknolojik Araştırma Kurumu (TÜBITAK). (2019). Öğretmenler İçin 4006-TÜBITAK Bilim Fuarları Kılavuzu. Ankara: Türkiye Bilimsel ve Teknolojik Araştırma Kurumu Başkanlığı.

Ünsal, F. (2019). Türkçe Derslerinde Rol Alma Modeli ile Hazırlanan Etkinliklerin Öğrencilerin Konuşma Tutum ve Kaygılarına Etkisi. Yüksek Lisans Tezi, Marmara Üniversitesi, Eğitim Bilimleri Enstitüsü, İstanbul.

Ünüvar, P. Çalışandemir, F. ve Tagay, Ö. (2018). Sosyal Medyada Mesleki Dayanışma: Okul Öncesi Öğretmenlerinin Mesleki Yardım Talepleri, International Journal of Eurasian Education and Culture, 4, 22-32.

Veenman, S. (1984). Perceived Problems of Beginning Teachers. Sage Journals. 54(2), 143-178.

Vural, Z. B. ve Bat, M. (2010). Yeni Bir İletişim Ortamı Olarak Sosyal Medya: Ege Üniversitesi illetişim Fakültesine Yönelik Bir Araştırma. Journal of Yaşar Universtiy, 5(20), 3348-3382.

Whiting, A. ve Williams, D. (2013). Why People Use Social Media: A Uses and Gratifications Approach. Qualitavite Merket Research: An Internaitonal Journal, 16(4), 362-369.

Yıldırım, A. ve Şimşek. H. (2011). Sosyal Bilimlerde Nitel Araştırma Yöntemleri. Ankara: Seçkin Yayınları.

\section{Introduction}

\section{Extended Abstract}

It is a compulsory need to get ideas from experienced teachers to solve the problems faced by teachers in the field and find solutions to their questions and problems instantly. Teachers need other teachers and their support in their professional activities (Ergüney, 2019, p. 2). In many countries, it has been determined that the teachers at the beginning of their professional lives are quite worn and it is stated that they should get support and help from other teachers in order to avoid this situation (Ingersoll \& Strong, 2011: 211; Long et al., 2012, p. 24). Groups set up by teachers on social media have positive effects and contribution to their professional development in order to exchange ideas with their colleagues, support their work, ask questions and answer their questions, and benefit from their experiences (Deniz, 2016, p. 86-87; Ergüney, 2019, p. 175-178; Afsin, 2019, p. 62). Teachers can share their work with their colleagues through social media, as well as reach their colleagues' work and experiences. This situation among teachers is a solidarity and can be an idea for pre-service and in-service needs determination studies obtained from channels such as social media (Ünüvar, Çalışandemir and Tagay, 2018, p. 22).

The skills which is acquired in course Turkish are an intermediate skill, but these are also mandatory factors for getting success because of supporting improvement of the courses. In the study, the shares in which Turkish teachers expressed their questions, suggestions and criticisms were examined. This study aims to reach many inferences about the functions and its applications of Turkish in the field. In the study, teachers' opinions, discussions and problems will be examined through authentic records on social media. This study is very important in terms of examining the problems of Turkish teachers through a wide perspective, gathering data from a natural environment where people express themselves freely, using a state-of-the-art communication tool such as social media, and reaching a lot of people. In the light of the general purpose of the study, the following research question was addressed "What are the questions, criticisms and suggestions of Turkish teachers on Facebook?". In order to achieve this general purpose, the sharing of Turkish teachers in grammar and grammar teaching, basic language skills, curricular activities, vocabulary teaching, professional development, course materials, and project preparation were examined. This study will open new horizons to Ministry of National Education in Turkey policies, education and training system and researchers.

\section{Method}

This study is designed as a case study, one of the qualitative research methods. The case study is that datas of case which are found in natural environment are gathered systematically, analyzed and it is told elobarete descriptions as it exists by questioning results of the case (Yıldırım \& Şimşek, 2016, p. 73). 
The data collection process of the study was as follows: In the first place, Facebook, the social media network with more users, was chosen to reach more people and observe more problems. In this study, the posts of a Turkish group on Facebook are taken into consideration as a study object. Then, groups created by Turkish teachers on Facebook were examined. Between the dates of September 1st, 2015 and August 31st, 2018, 8372 posts in the group were collected by the researcher with the "Screen Capture Tool".

Content analysis is a systematic and objective technique which has stages whereby datas found code with certain rules, subjects are determined, codes and subjects are arranged and defined in order to explain and make sense datas found by answering a few reserach questions in different fields (Yıldırım and Şimşek, 2016, p. 242).

\section{Result and Discussion}

According to the results of the research, Turkish teachers consulted with each other mostly about "grammar and grammar teaching" (3560), "developing basic language skills" (2079), "in-school activities" (979), "vocabulary teaching" (632), "professional development" (452) exchanged information on "measurement and evaluation" (392), "course materials" (388), "projects" (250).

The teachers exchanged views among the grammar topics for "additions and roots" the most. The least discussion was made on the "slash". It was determined that Turkish teachers were in contradiction by sharing about almost all grammar issues at different times and often, and they wanted to resolve the issues that they could not fully decide. In this context, it can be said that the biggest problem in teaching grammar is that there is no reference or reference source. The second issue that Turkish teachers have problems is about developing their language skills. Thet talked about "reading" ( $f=1.929)$, "writing" ( $f=67)$, "listening" ( $f=57$ ) and "speaking" $(f=29)$ related to language skills. Throughout the school, teachers did made many practices in the classroom and it was observed that they share their work with their members. It was determined that Turkish teachers shared the boards in the school and class for certain days and weeks, programs prepared for ceremonies, authors' birth and death anniversary studies, and activities organized for ceremonies with their colleagues. It was determined that a significant number of teachers applied various activities ( $f=120)$ for vocabulary teaching and they wanted to share them. Some teachers were also found to be seeking practice for vocabulary teaching $(f=50)$. School exams $(f=152)$ were discussed the most in the main theme of measurement and evaluation. Most of the Turkish teachers prepared their own exams in school exams $(f=120)$ and sometimes asked for exam samples $(f=30)$. Considering this result, it can be said that teachers are sufficient in terms of measurement and evaluation. The topics which Turkish teachers consulted least were the projects. In this theme, subthemes of TÜBITAK Science Fair $(f=209)$ and school project assignments $(f=41)$ are discussed. It was determined that the teachers shared the projects they prepared for the science fair with other teachers $(f=136)$.

In order for Turkish teachers and other branch teachers to be successful in the field, to increase the quality of education and training, questions, opinions, suggestions and ideas should be collected frequently and regulations should be made in the education and training system in line with these feedbacks. 